Гальчинський Л.Ю. канд. техн. наук., доцент ORCID ID 0000-0001-6795-3517

Національний технічний університет України «Київський політехнічний інститут імені горя Сікорського»

\title{
ОЦІНКА СУКУПНОЇ ВАРТОСТІ ВОЛОДІННЯ ОПЕРАЦІЙНИМИ СИСТЕМАМИ В ОРГАНАХ ДЕРЖАВНОЇ ВЛАДИ
}

\author{
ОЦЕНКА СОВОКУПНОЙ СТОИМОСТИ ВЛАДЕНИЯ ОПЕРАЦИОННЫМИ \\ СИСТЕМАМИ В ОРГАНАХ ГОСУДАРСТВЕННОЙ ВЛАСТИ
}

\section{ASSESMENT OF THE TOTAL COST OF OWNERSHIP OF OPERATION SYSTEMS IN THE PUBLIC AUTHORITIES}

Стаття присвячена дослідженню проблеми використання операційних систем в органах державної влади України. Оскільки більша частина використовуваних систем $\epsilon$ застарілими, у сучасних умовах витрати на їх підтримку э значними, проте можуть бути ще більшими. Це обумовлено додатковими витратами на здійснення комплексу заходів для забезпечення необхідного рівня сумісності з прикладними програмами, зменшення ризику втрати даних через вихід систем з ладу та впровадження додаткових механізмів захисту від кібератак. Для оцінки вартості володіння операційними системами запропоновано застосувати методику розрахунку сукупної вартості володіння (Total Cost of Ownership (ТСО) виходячи з рівня сукупних витрат на IT. На прикладі Державної фіскальної служби Украӥни розраховано вартість володіння операційними системами Windows з урахуванням сучасної організаційної структури, загальних витрат на IT та інших ключових показників діяльності служби. Ряд припущень дозволив отримати реальну оичінку вартості володіння, на основі якої запропоновано можливі варіанти оптимізаиії витрат.

Ключові слова: операційні системи, державний сектор, сукупна вартість володіння.

Статья посвящена исследованию проблемы использования операционных систем в органах государственной власти Украины. Поскольку большая часть используемых систем являются устаревшими, в современных условиях затраты на их поддержку являются значительными, однако могут быть еще большими. Это обусловлено дополнительными расходами на осуществление комплекса мероприятий для обеспечения требуемого уровня совместимости с прикладными программами, уменьшение риска потери данных из-за выхода систем из строя и внедрения дополнительных механизмов защиты от кибератак. Для оценки стоимости владения операционными системами предложено применить методику расчета совокупной стоимости владения (Total Cost of Ownership (ТCO) исходя из уровня совокупных затрат на ИТ. На примере Государственной фискальной службы Украины рассчитано стоимость владения операчионными системами Windows с учетом современной организачионной структуры, общзи расходов на ИТ и других ключевых показателей деятельности службы. Ряд предположений позволил 
получить реальную оценку стоимости владения, на основе которой предложень возможные варианты оптимизации расходов.

Ключевые слова: операционные системы, государственный сектор, совокупная стоимость владения.

Article is devoted to a research of a problem of use of operating systems in public authorities of Ukraine. As the most part of the used systems are obsolete, in modern conditions of costs for their maintenance are considerable, however can be still big. It is caused by additional expenses on implementation of a complex of actions for ensuring required level of compatibility with application programs, reduction of risk of loss of data through an exit of systems out of operation and implementation of additional mechanisms of protection against cyber-attacks. It is offered to apply a method of calculation of aggregate value of ownership to a value assessment of ownership of operating systems (Total Cost of Ownership (TCO) proceeding from the level of total costs for IT. On the example of the Public fiscal service of Ukraine it is expected the cost of ownership of the Windows operating systems taking into account a modern organizational structure, total expenditures on IT and other key indicators of activities of service. A number of assumptions allowed to receive a real value assessment of ownership on the basis of which possible options of an expense optimization are offered.

Keywords: operating systems, public sector, total cost of ownership.

Вступ. Подібно будь-якій сучасній організації органи державної влади для забезпечення своєї діяльності використовують інформаційні технології (IT), зокрема програмне забезпечення (ПЗ). Операційна система (ОС) $є$ базовим програмним забезпеченням, яке через взаємодію 3 апаратним забезпеченням (АЗ) надає інтерфейс для запуску прикладних програм, створених для вирішення різноманітних задач, тому стаття присвячена саме цьому програмному продукту.

Згідно з останнім звітом [5] в органах виконавчої влади в якості ОС використовуються різні версії MS Windows, більша частина - 3 яких $\epsilon$ застарілими та офіційно не підтримуються розробником [12]. Без підтримки розробника вартість володіння таким інформаційними активами може зрости, адже для забезпечення необхідного рівня інформаційної безпеки, надійності роботи прикладних програм та сумісності 3 більш новими системами необхідно впроваджувати відповідні компенсаційні механізми захисту та резервного збереження даних, забезпечувати сумісність 3 новими протоколами передачі даних та форматами. Все це в кінцевому результаті часто призводить не тільки до збільшення витрат часу на адміністрування та зростання штату ІТ-спеціалістів, а i до прямих витрат на закупівлю додаткових IT продуктів. В іншому випадку, без здійснення додаткових заходів, зростає ризик простою в наслідок виходу ОС з ладу через помилки, зовнішнього втручання в роботу в результаті кібернападу та просто втрати даних. Оновлення до нової версії ОС в подібних ситуаціях може стати більш економічно виправданим рішенням ніж підтримка застарілих систем. Крім того, згідно рекомендацій Державного центру кіберзахисту та протидії 
кіберзагрозам Держспецзв'язку, такий крок допоможе зменшити кількість вразливостей програмного забезпечення і тим самим підвищити рівень безпеки даних [3].

Інвентаризація інформаційних активів та оцінка вартості володіння ними $\epsilon$ першочерговими завданнями для досягнення ефективності в процесах їх експлуатації. Ці питання широко розглядались у роботах зарубіжних (Andresen J. L. [14], Cronk M. A. [15], Patel N. V. [16], Remenyi D. [17], Деверадж С. [1], Середенко Е.С. [11], Мухин Ю. Ю., Коссова Е. В. [8]) та українських (Рибидайло А.А., Поривай О.В., Бобров С.В., Солошенко Н.В. [9]) науковців.

Інвентаризація інформаційних активів (і ОС в тому числі) періодично проводиться Державною службою інтелектуальної власності України, проте отримані дані можуть бути не репрезентативними. Наприклад, «у процесі інвентаризації комп'ютерних програм органами виконавчої влади допускаються численні помилки та неточності, що не дає можливості визначити реальну кількість та перелік таких програм» [2]. Імовірно у зв'язку 3 цим розрахунок та аналіз сукупної вартості володіння ОС в органах державної влади раніше не проводився.

Постановка завдання. Метою статті $\epsilon$ визначення сукупної вартості володіння операційними системами в органах державної влади. Основним завданням $\epsilon$ застосування методології розрахунку сукупної вартості володіння операційними системами 3 урахуванням сучасної організаційної структури органів державної влади та актуальних економічних показників на прикладі Державної фіскальної служби України (ДФС).

Методологія визначення сукупної вартості володіння не $\epsilon$ новою. Питання оцінки вартості затрат на закупівлю, установку, інтеграцію, сервісне обслуговування i подальшу модернізацію інформаційних систем почало активно досліджуватись у 80-90-ті роки 20-го століття. Спочатку для цих цілей застосовували універсальні методики оцінки ефективності затрат, які використовувались при оцінці інвестиційних проектів. Згодом, 3 розвитком інформаційних технологій, універсальні методи все більше враховували специфіку і особливості галузі.

В даний час існує цілий ряд методів для оцінки параметрів ефективності тієї чи іншої інформаційної системи. Їх застосування обумовлено зростаючою конкуренцією виробників, що використовують зазначені методики для демонстрації переваги власних розробок і зростанням кількості досліджень, що проводяться під час передпроектної та проектної стадій при створенні великих інформаційних систем [8].

Усі сучасні методи були детально проаналізовані у роботі Середенко проте класичний метод Total cost of ownership (TCO), розроблений Microsoft та Interpose, виявився найбільш зручним у використанні для проектів 
державного сектору [11]. Колектив авторів на чолі з Рибидайло А.А. охарактеризував його як найбільш доречний з точки зору застосування у сучасних умовах України [9].

Метод складається з наступних кроків:

- аналіз структури витрат для кожного типу обладнання (серверів, клієнтів, принтерів тощо);

- класифікація устаткування (портативні/настільні комп'ютери, сервери файлів, прикладне програмне забезпечення, операційні системи);

- оцінка особливостей кожного типу устаткування;

- поділ загальних витрат на прямі та непрямі витрати.

У моделі сукупної вартості володіння до складу прямих витрат включені:

- апаратно-програмні засоби (капітальні вкладення і відрахування по ліцензіях на нові системи, модернізацію та відновлення);

- адміністрування (мережеве та системне адміністрування, аутсорсинг, а також вирішення поточних завдань);

- підтримка (служба технічної підтримки, навчання, матеріальнотехнічне постачання, відрядження, договори на обслуговування та підтримку, а також накладні видатки);

- розробка (створення додатків, тестування і підготовка документації, у тому числі розробка нових проектів, адаптація до вимог замовників й обслуговування);

- оплата послуг зв'язку (виділеної лінії та Інтернет).

Непрямі витрати пов'язані 3 кінцевими користувачами (витрати на самонавчання та допомогу іншим користувачам) і з втратами, викликаними плановими та позаплановими простоями [10].

Результати дослідження. На прикладі ДФС було проведено оцінку сукупної вартості володіння ОС. Інформаційною базою дослідження стали відкриті дані про організаційну структуру територіальних підрозділів ДФС в усіх областях, містах та селищах України у 2016 році [4], виконані плани закупівель на кінець 2016 року [11], кількість державних службовців та їх посади у 2016 році [4], дані щодо оплати праці державних службовців у 2016 році в залежності від їх посад та категорій [10]. Результати розрахунків можуть мати неточності обумовлені якістю відкритих даних, представлених на офіційних інтернет-порталах відповідних органів державної влади.

Для визначення сукупної вартості володіння ОС у ДФС було попередньо проведено розрахунок сукупної вартості володіння всіма IT ресурсами. Це пов'язано з тим, що ОС часто купується разом з ПК або як частина інших більш складних комплексів і окремо може не виділятися у бухгалтерському обліку [7]. В офіційних звітах щодо закупівель та фінансовій звітності представлені загальні цифри без детальної класифікації за типами ПЗ. 
Відповідно надалі було зроблено ряд припущень, для визначення частки затрат від загальної вартості володіння IT ресурсами, які пов'язані 3 володінням ОС:

- всі працівники ДФС є користувачами ПК і використовують ОС Microsoft Windows XP, яка згідно [5] $\epsilon$ найбільш розповсюдженою в органах державної влади;

- середня заробітна плата користувача $\epsilon$ середньою зарплатою серед всіх категорій державних службовців не залежно від території, на якій вони працюють;

- накладні витрати збільшують величину оплати праці на розмір єдиного соціального внеску (ССВ);

- вартість однієї робочої години розраховується виходячи 3 кількості робочих днів у 2016 році;

- максимальний термін використання комп'ютерного обладнання та ПЗ становить 10 років згідно Норми зносу на необоротні активи бюджетних установ [6]. Станом на 2016 рік все комп'ютерне обладнання та ПЗ продовжує використовуватись;

- середні вартості ПК та обладнання для розрахунку узяті у цінах 2009 року, а кількість додаткового обладнання (принтери) узята виходячи із пропорції 1 на 10 співробітників;

- користувачі не займаються самостійним налаштуванням комп'ютерів та ПЗ - ці роботи виконуються співробітниками IT підрозділів.

Результати розрахунку сукупної вартості володіння всіма IT ресурсами ДФС наведені таблиці.

Таблиия

Розрахунок сукупної вартості володіння IT ресурсами ДФС у 2016 за методикою ТСО

\begin{tabular}{|c|l|c|c|}
\hline № п/п & Категорія & $\begin{array}{c}\text { Одиниця } \\
\text { виміру }\end{array}$ & Сума \\
\hline 1 & Базові показники для розрахунку & $\%$ & 22 \\
\hline 1.1 & Ставка єдиного соціального внеску (ССВ) & чол. & 16546 \\
\hline 1.2 & Кількість користувачів ПК в організації & грн. & 5631,70 \\
\hline 1.3 & Середня заробітна плата користувача на місяць & грн. & 6870,68 \\
\hline 1.4 & $\begin{array}{l}\text { 3 урахуванням накладних витрат (сплати ССВ) середня } \\
\text { заробітна плата на місяць }\end{array}$ & днів & 251 \\
\hline 1.5 & Кількість робочих днів у 2016 році & грн. & 41,06 \\
\hline 1.6 & Вартість однісї години роботи & од. & 230 \\
\hline 1.7 & Кількість підрозділів згідно організаційної структури ДФС & чол. & 560 \\
\hline 1.8 & $\begin{array}{l}\text { Кількість ІТ спеціалістів згідно організаційної структури } \\
\text { ДФС }\end{array}$ & років & 10 \\
\hline 1.9 & $\begin{array}{l}\text { Максимальний термін корисного використання обладнання } \\
\text { та ПЗ }\end{array}$ & \\
\hline
\end{tabular}




\begin{tabular}{|c|c|c|c|}
\hline № п/п & Категорія & $\begin{array}{c}\text { Одиниця } \\
\text { виміру }\end{array}$ & Сума \\
\hline 1.10 & Середня початкова вартість ПК з ОС & грн. & 4000,00 \\
\hline 1.11 & Кількість додаткового обладнання (принтери, сканери і т.д.) & шт. & 1655 \\
\hline 1.12 & Середня початкова вартість додаткового обладнання & грн. & 1500 \\
\hline 2. & Устаткування та програмне забезпечення. Прямі витрати & & \\
\hline 2.1 & Середньорічні витрати на закупівлю устаткування & млн. грн. & 125,07 \\
\hline 2.2 & Середньорічні витрати на програмне забезпечення & млн. грн. & 3,71 \\
\hline 2.3 & $\begin{array}{l}\text { Щорічна сума амортизації капітальних вкладень в } \\
\text { устаткування й П3 }\end{array}$ & млн. грн. & 6,87 \\
\hline 2.4 & Щорічні витрати на комплектуючі & тис. грн. & 199,56 \\
\hline 2.5 & $\begin{array}{l}\text { Річні витрати на оренду устаткування/програмного } \\
\text { забезпечення }\end{array}$ & тис. грн. & 25,38 \\
\hline \multicolumn{2}{|c|}{$\begin{array}{l}\text { Загальна річна вартість устаткування та програмного } \\
\text { забезпечення }\end{array}$} & млн. грн. & 135,86 \\
\hline 3 & Управління і персонал. Прямі витрати & & \\
\hline 3.1 & Витрати на заробітну плату персоналу за категоріями на рік: & & \\
\hline 3.1 .1 & Керівників департаментів IT & тис. грн. & 82,70 \\
\hline 3.1 .2 & Заступників керівників департаментів IT & тис. грн. & 144,74 \\
\hline 3.1 .3 & Керівників управлінь IT & млн. грн. & 1,26 \\
\hline 3.1 .4 & Заступників керівників управлінь IT & млн. грн. & 1,09 \\
\hline 3.1 .5 & Керівників відділів IT & млн. грн. & 4,84 \\
\hline 3.1 .6 & Заступників відділів IT & млн. грн. & 4,17 \\
\hline 3.1 .7 & Керівників секторів IT & млн. грн. & 3,33 \\
\hline 3.1 .8 & Спеціалісти (адміністрування, підтримка) & млн. грн. & 12,20 \\
\hline \multicolumn{2}{|c|}{$\begin{array}{l}\text { Загальна заробітна плата персоналу відділу інформаційних } \\
\text { технологій на рік }\end{array}$} & млн. грн. & 27,11 \\
\hline \multicolumn{2}{|c|}{$\begin{array}{l}3 \text { урахуванням накладних витрат (сплати ССВ), річні витрати на } \\
\text { персонал }\end{array}$} & млн. грн. & 33,08 \\
\hline 3.2 & Відрядні витрати за рік & тис. грн. & 105,00 \\
\hline 3.3 & $\begin{array}{l}\text { Консультаційні послуги третіх фірм та інші витрати на } \\
\text { обслуговування }\end{array}$ & млн. грн. & 4,31 \\
\hline 3.4 & $\begin{array}{l}\text { Витрати на делеговані іншим організаціям завдання } \\
\text { (аутсорсинг) }\end{array}$ & тис. грн. & 107,6 \\
\hline 3.5 & Витрати на навчання IT-персоналу в рік & тис. грн. & 629,40 \\
\hline 3.6 & Вартість обслуговування техніки за контрактами & тис. грн. & 781,02 \\
\hline \multicolumn{2}{|c|}{ Усього управлінських витрат і витрат на персонал } & млн. грн. & 39,01 \\
\hline 4 & Розвиток. Прямі витрати & & \\
\hline 4.1 & Щорічні витрати на заробітну плату за напрямками розробки: & & \\
\hline 4.1 .1 & Проектування & грн. & 0,00 \\
\hline 4.1 .2 & Розробка & грн. & 0,00 \\
\hline 4.1 .3 & Тестування & грн. & 0,00 \\
\hline 4.1 .4 & Документування & грн. & 0,00 \\
\hline 4.2 & $\begin{array}{l}\text { Щорічні витрати на заробітну плату по супроводу наявних } \\
\text { систем за напрямками: }\end{array}$ & & \\
\hline 4.2 .1 & Проектування & грн. & 0,00 \\
\hline 4.2 .2 & Розробка & грн. & 0,00 \\
\hline
\end{tabular}




\begin{tabular}{|c|c|c|c|}
\hline № п/ா & Категорія & $\begin{array}{c}\text { Одиниця } \\
\text { виміру }\end{array}$ & Сума \\
\hline 4.2 .3 & Тестування & грн. & 0,00 \\
\hline 4.2 .4 & Документування & грн. & 0,00 \\
\hline \multicolumn{2}{|c|}{ Загальні витрати на розробку та підтримку } & грн. & $\mathbf{0 , 0 0}$ \\
\hline \multicolumn{2}{|c|}{$\begin{array}{l}3 \text { урахуванням накладних витрат загальна сума витрат на оплату } \\
\text { розробки та підтримки }\end{array}$} & грн. & $\mathbf{0 , 0 0}$ \\
\hline 4.3 & $\begin{array}{l}\text { Щорічні витрати на оплату послуг консультантів або } \\
\text { сервісних організацій у частині розвитку }\end{array}$ & млн. грн. & 8,67 \\
\hline \multicolumn{2}{|c|}{ Всього щорічні витрати на розвиток } & млн. грн. & 8,67 \\
\hline 5 & Зв’язок. Прямі витрати & & \\
\hline 5.1 & Щорічні витрати на оренду виділених ліній і каналів зв'язку & млн. грн. & 1,43 \\
\hline 5.2 & $\begin{array}{l}\text { Щорічні витрати на віддалений доступ по спеціальним лініям } \\
\text { зв'язку та Інтернет }\end{array}$ & млн. грн. & 1,37 \\
\hline 5.3 & Річна вартість корпоративних мереж передачі даних & млн. грн. & 18,54 \\
\hline \multicolumn{2}{|c|}{ Загальні витрати на зв'язок } & млн. грн. & 21,34 \\
\hline \multicolumn{2}{|c|}{ Загальні прямі витрати } & млн. грн. & 204,88 \\
\hline 6 & Витрати користувача на IT. Непрямі витрати & & \\
\hline 6.1 & $\begin{array}{l}\text { Кількість годин на самонавчання роботі з комп'ютером і ПЗ } \\
\text { одного користувача }\end{array}$ & год. & 40 \\
\hline 6.2 & $\begin{array}{l}\text { Кількість годин, що витрачаються одним користувачем на } \\
\text { обслуговування файлів, комп'ютера й програм, написання } \\
\text { скриптів і програм }\end{array}$ & год. & 0 \\
\hline 6.3 & $\begin{array}{l}\text { Річна вартість діяльності користувача у зв'язку з наявністю в } \\
\text { нього ПК на рік }\end{array}$ & грн. & 1642,39 \\
\hline \multicolumn{2}{|c|}{$\begin{array}{l}\text { Загальна річна вартість діяльності користувачів у зв'язку з } \\
\text { наявністю ПК }\end{array}$} & млн. грн. & 27,18 \\
\hline 7 & Простої. Непрямі витрати & & \\
\hline 7.1 & $\begin{array}{l}\text { Кількість годин простою на місяць у зв'язку із } \\
\text { плановими/позаплановими зупинками в роботі } \\
\text { мережі/системи }\end{array}$ & год. & 2 \\
\hline 7.2 & $\begin{array}{l}\text { Загальна кількість загублених годин за рік у результаті } \\
\text { простою }\end{array}$ & год. & 397104 \\
\hline \multicolumn{2}{|c|}{ Загальна річна собівартість простоїв } & млн. грн. & 16,31 \\
\hline \multicolumn{2}{|c|}{ Всього непрямих витрат } & млн. грн. & 43,48 \\
\hline \multicolumn{2}{|c|}{ Загальна річна сукупна вартість володіння IT ресурсами } & млн. грн. & 248,36 \\
\hline \multicolumn{2}{|c|}{$\begin{array}{l}\text { Загальна вартість володіння IT ресурсами розраховуючи на одне } \\
\text { робоче місце }\end{array}$} & тис. грн. & 15,01 \\
\hline \multicolumn{2}{|c|}{$\begin{array}{l}\text { Загальна річна собівартість володіння ОС (6\% від загальної річної } \\
\text { вартості володіння ІT ресурсами) }\end{array}$} & млн. грн. & 14,90 \\
\hline \multicolumn{2}{|c|}{$\begin{array}{l}\text { Загальна вартість володіння ОС розраховуючи на одне робоче } \\
\text { місце }\end{array}$} & грн. & 900,61 \\
\hline
\end{tabular}

У структурі плану закупівель ДФС у 2016 році суми коштів на підтримку та закупівлю/аренду програмного та апаратного забезпечення представлені постатейно для ключових типів IT ресурсів (обладнання, програмне забезпечення, канали зв'язку), проте не містять окремих відомостей щодо розміру затрат виключно на підтримку ОС комп'ютерів держслужбовців. Оскільки без цього базового компоненту використання інших компонентів IT 
неможливе, для розрахунків було зроблено припущення щодо частки від загального обсягу затрат на підтримку, обслуговування та розвиток сервісів, систем та мереж, яка витрачається на підтримки та обслуговування ОС. Припущення полягає у наступному:

- найчастіше ОС купуються як частина нового комп'ютера i далі у бухгалтерському обліку для зручності не відокремлюється. Це означає що ОС амортизується як частина ПК. Загальні затрати на амортизацію ПЗ та АЗ складає 2,66\% від загальної вартості володіння IT ресурсами. Якщо прийняти до уваги той факт, що ОС складають $12,63 \%$ від загальної кількості ПЗ, яке використовується на ПК державних службовців [5], то затрати на амортизацію ОС складатимуть $0,34 \%$ від загальної вартості володіння IT.

- самостійна доробка ОС $є$ неможливою, оскільки це пропрієтарний продукт із закритим початковим кодом. Через це іще однією складовою затрат на володіння ОС $\epsilon$ затрати, пов'язані 3 оплатою праці IT спеціалістів, які займаються іiі адмініструванням (встановлення, конфігурування, тестування та встановлення оновлень). Згідно розрахунків управлінські витрати та витрати на оплату праці складають $15,71 \%$ від загальної вартості володіння IT. Третина цього часу, тобто $5,24 \%$ витрачається на адміністрування ПЗ, зокрема ОС.

- Сума затрат на амортизацію та затрат на оплату праці працівників IT підрозділів ДФС становить 5,24\% + 0,34\% $=5,58 \approx 6 \%$ від загальної вартості володіння IT.

Висновки. Вперше було проведено оцінку сукупної вартості володіння операційними системами, які використовуються в органах державної влади (на прикладі ДФС). Отримані результати розрахунків та проведений аналіз вказують на таке:

- ОС, які використовуються державному секторі загалом та у ДФС зокрема потребують оновлення;

- сукупна вартість володіння застарілою ОС для 16546 робочих місць складає 14,9 млн. грн. на рік. Висока вартість володіння пояснюється великою кількістю спеціалістів IT підрозділів, які займаються адмініструванням. Застарілі технології, в тому числі обмеженість функціоналу ОС, не дозволяють проваджувати більш ефективні рішення, які б допомогли скоротити витрати;

- відсутність оновлень ОС залишають незакритими вразливості, які можуть бути використані кіберзловмисниками при спробі викрасти конфіденційні дані. Для запобігання такому сценарію необхідно використовувати додаткові засоби захисту, які в свою чергу вимагають додаткових інвестицій та затрат часу на адміністрування; 
- втрати від простоїв співставні з сукупною вартістю володіння ОС, яка також $\epsilon$ причиною їх виникнення. Використання більш надійної та сучасної версії ОС потенційно може скоротити витрати не тільки на адміністрування, а зменшити втрати від простоїв.

Результати дослідження можуть бути використані для розробки плану оптимізації використання IT ресурсів та оновлення ОС, а також у інших дослідження даного спрямування, які стосуватимуться органів державної влади.

\section{Література:}

1. Деверадж С. Тайны ИТ: Измерение отдачи от инвестиций в информационные технологии / С. Деверадж, Р. Кохли // Букпресс. - 2006. - 192 с.

2. Державна служба інтелектуальної власності України. Річний звіт 2015 [Електронний ресурс] - Режим доступу: http://sips.gov.ua/i_upload/file/zvit_2015_ua.pdf.

3. Державна служба спеціального зв'язку та захисту інформації України Загальні рекомендації Державного центру кіберзахисту та протидії кіберзагрозам Держспецзв'язку для підвищення рівня захисту інформаційних ресурсів та систем і для запобігання кіберінцидентам в установах, на підприємствах і в організаціях [Електронний pecypc] - Режим доступу: http://cert.gov.ua/pdf/reccomends.pdf.

4. Державна фіскальна служба України. Структура [Електронний ресурс] Режим доступу: http://sfs.gov.ua/pro-sfs-ukraini/struktura-/

5. Державне агентство з питань науки, інновацій та інформатизації України | Доповідь про стан інформатизації та розвиток інформаційного суспільства в Україні за 2013 рік. [Електронний ресурс] - Режим доступу: http://dknii.gov.ua/?q=node/1469.

6. Додаток до Положення 3 бухгалтерського обліку необоротних активів бюджетних установ (пункт 8.7).

7. Омельницкая 3. Компьютерная техника в учете предприятия [Електронний pecypc] - Режим доступу: https://uteka.ua/publication/Kompyuternaya-texnika-v-uchetepredpriyatiya- 2 .

8. Мухин Ю. Ю. Подходы к оценке полной (совокупной) стоимости владения (ТСО) для медицинских информационных систем / Ю. Ю. Мухин, Е. В. Коссова // Информационно-измерительные и управляющие системы. - 2010. - №12, т.8. - С. 54-61.

9. Підходи щодо оцінки сукупної вартості володіння інформаційною технологією / Рибидайло А.А., Поривай О.В., Бобров С.В., Солошенко Н.В. // Збірник наукових праць Центру воєнно-стратегічних досліджень Національного університету оборони України імені Івана Черняховського. - 2014. - № 3. - С. 80-85.

10. Постанова Кабінету Міністрів України від 6 квітня 2016 р. № 292 «Деякі питання оплати праці державних службовців у 2016 році».

11. Річний план закупівель на 2016 рік Державної фіскальної служби України [Електронний ресурс] - Режим доступу: http://sfs.gov.ua/data/material/000/206/279763/2016_12_23_R_chniy_plan_2016_DFS.PDF

12. Середенко Е. С. Оценка экономической эффективности аналитических информационных систем: Дис. канд. эк. наук: 08.00.13 / Середенко Евгений Сергеевич; Московский Государственный университет им. М. В. Ломоносова. - М.: 2014. - 166 с.

13. Срок окончания поддержки Windows XP, Office 2003 - 2014 год | Bce о поддержке Windows XP [Електронний pecypc] - Режим доступу: http://www.microsoft.com/ru-ru/windows/endofsupport.aspx 
14. Тюріна Н. М. Оцінка вартості та ефективності використання інформаційних систем управління на промислових підприємствах / Н. М. Тюріна, В.Т. Параконний // Вісник Хмельницького національного університету. Економічні науки. - 2006. - № 2, т. 2. C. 22-27.

15. Andresen J. L. A Framework for Selecting an IT Evaluation Method: in the Context of Construction / J. L. Andresen // Danmarks Tekniske Universitet. - 2001. - 257 p.

16. Cronk M. A. Conceptual Framework for Furthering Understanding of 'IT business value' and its Dimensions / M. Cronk, E. Fitzgerald // PACIS 1997 Proceedings. - 1997. - pp. 405-415.

17. Patel N. V. Evaluating information technology in dynamic environments: a focus on tailorable information systems / N. V. Patel, Z. Irani // Logistics Information Management. 1999. - Vol. 12. - pp. 32-39.

18. Remenyi D. The Effective Measurement and Management of IT Costs and Benefits / D. Remenyi, A. Money, M. Sherwood-Smith // Oxford: Butterworth-Heinemann. - 2000. - 362 p. 